\title{
Study of Some Nutritional and Hematological Parameter of Normal Pregnant
}

\section{Woman}

\section{Shaimaa A. Qaisar", Dr.Rafiq Muhammad S. Rashid ${ }^{* *}$}

"M.Sc. Food Science and Human Nutrition University of Garmian, College of Education

** Assistant Professor of Human Nutrition University of Sulaimani, College of Agriculture

\section{Abstract}

The present study was carried out from February 2014 until February 2015, at Halabja governorate, and include (60) sixty pregnant women who were regularly visiting the clinical center "maternity hospital", and the investigation aimed to evaluate and study the nutritional and healthy state of pregnant women by estimating the hematological tests. The cases were divided into three groups according to pregnant ages $\mathrm{A}(16-24), \mathrm{B}(24-32)$ and $\mathrm{C}(32-41)$ years, and the period of study take last 5 months for pregnant women and first postpartum.

The results of our study summarized as following:

1. Generally gestation weight gain were between $4-14 \mathrm{Kg}$ for three groups, and means of weight gain for each (three) group; A, B, C were 9.70, 9.06, 8.62 $\mathrm{kg}$ respectively.

2. All hematological parameters (CBC tests) of pregnant women during last five months and first postpartum month As the general, the mean \pm SEM; results of $\mathrm{WBC}, \mathrm{RBC}, \mathrm{PLT}, \mathrm{Hb}, \mathrm{PCV}, \mathrm{MCV}, \mathrm{MCV}$ and $\mathrm{MCHC}$ were 8.88 $\pm 0.12\left(10^{3} / \mu \mathrm{L}\right), 4.1 \pm 0.02\left(10^{9} / \mu \mathrm{L}\right), 224.05 \pm 2.84\left(10^{3} / \mu \mathrm{L}\right), 12.05 \pm$ $0.07(\mathrm{mg} / \mathrm{dl}), \quad 36.77 \pm 0.20 \%$ and $90.1 \pm 0.44(\mathrm{fl}), \quad 29.53 \pm 0.15(\mathrm{pg})$ and $32.81 \pm 0.08(\mathrm{~g} / \mathrm{dL})$ respectively.) as the result of increasing the blood volume during pregnancy which leads to physiologic anemia.

3. The serum iron level ranged between 86.32- $97.84 \mu \mathrm{g} / \mathrm{dl}$ during last 5 months of pregnancy. 
4. Lipid profile results were variable during the period of last 5 month of pregnancy, and as total means volumes of each TG, TC, HDL, LDL and VLDL were, 176.60, 205.61, 53.28, 117.33 and $80.51 \mathrm{mg} / \mathrm{dl}$ respectively.

\section{INTRODUCTION}

Halabja as this study conducted is a town in Kurdistan-Iraq, located about $240 \mathrm{~km}$ north - east of Baghdad total population in 2013 was 117,000 capita (http://krg.org/articles). Total deliveries of Halabja in 2014 was 2380 newborns and 23 dead newborns, normal delivery was 1474 and 912 cesarean delivery. While in 2015 deliveries were 2400 babies (Halabja maternity hospital).

Pregnancy period divided into three time, called trimesters. Many physiological, biochemical and physical changes occur in normal pregnancy as well as some of complications may impact nutritional and health status including heart burn, constipation, anemia, edema, nausea and vomiting (Ministéri, 2005). Maternal and child health is an important problem of public health, influencing the development of the family and the community (Victoria et al., 2001). During pregnancy, women face a higher risk of developing gestational diabetes, gestational hypertension, as well as preeclampsia. The external risk factor for pregnant women and newborn health comes from unbalanced nutrition for pregnant women, besides many other factors such as mother age, height, and weight, smoking, consuming of alcoholic beverages, and other social factors (CDC, 2005).

The research project aimed to study and evaluate the nutritional and health status of pregnant women in Halabja town. Some inquisitive points concluded on the subject are given below:

1. Random selection cases for pregnant women are chosen at the different age, living standard and number of pregnancies or multigravida.

2. To perform questionnaire regarding the amount of food intake, food quality and the necessary information of previous pregnancies.

3. To evaluate some parameters and hematological tests of pregnant women. 


\section{Complications and changes during Pregnancy:}

Gestational complications, with unfavorable outcomes for mothers and children, have also been associated with both insufficient and excessive gestational weight gain. Among these outcomes low birth weight, microsomal, preterm birth, cesarean and maternal diabetes and hypertension are prominent (Crane et al., 2009; Frederick et al., 2008).

Anemia is having lower than the normal number of healthy red blood cells. Treating the underlying cause of the anemia will help restore the number of healthy red blood cells. Women with pregnancy related anemia may feel tired and weak. This can be helped by taking iron and folic acid supplements. Health care provider will check your iron levels throughout pregnancy (CDC, 2014). In a healthy pregnancy, there are considerable changes in the composition of blood brought about by an increase in total blood volume and hemostatic changes which help to prevent hemorrhage at delivery. Plasma volume increases by at least $40 \%$ and there is an increase in red cell mass of $18-25 \%$, providing the iron status is normal. This affects the hemoglobin level which reaches a physiological low at 32 weeks' gestation. In women with good iron stores the hemoglobin returns to a normal level within two to three weeks postpartum (WHO, 2002).

Gestational diabetes mellitus (GDM) is defined by the American Diabetes Association (ADA) as any degree of glucose intolerance with onset or first recognition during pregnancy (ADA, 2012).

Pregnancy is accompanied by significant variations in maternal lipid metabolism (Stock and Metcalfe, 1994). Increase in maternal lipid profile during pregnancy differs with trimester. It has been observed that the concentration of serum total cholesterol, serum triglyceride, high-density lipoprotein (HDL) and low density lipoprotein (LDL) in normal pregnant women increased with increasing gestational age (Fahraeus et al., 1995; Jimenez et al., 1988; Potter and Neste, 1979). Wald and Guckle, (1988) observed that the increase in the maternal lipid 
profile in the third trimester is due to the maternal switch from carbohydrate to fat metabolism which is an alternative pathway for energy generation due to high energy demand.

The hematological indices of an individual to a large extent reflect their general health (WHO, 2004). It is also acknowledged that for comparisons between individuals and with reference data in a clinical diagnostic situation, it is necessary to consider the normal variations due to sex, age, and breed in order to increase diagnostic precision (James et al., 2008). In normal pregnancy the hematological indices of an individual to a large extent reflect their general health (WHO, 2004) and many studies such as Osonuga et al., (2011) and Shaw et al., (2010) have identified the hematological indices of the pregnant woman as one of the factors affecting pregnancy. Anemia (low hemoglobin) is a widely identified hematological abnormality (CDC, 2005) and it is also associated with adverse pregnancy outcome (Garn(a) et al., 1981).

\section{Methods:}

This study conducted from February 2014 until February 2015 by randomly taking 60 cases (Pregnant women) in Halabja governorate center hospital delivery and children and Anab hospital. In this study cases were randomly selected for the purpose of conducting the study during pregnancy in about the middle pregnancy( 2nd Trimester period) until the end of pregnancy (at birth) and also for one months after birth. The cases were divided into three categories based on age and gestation period:

1- The pregnant women, at 16 to 23 years of age.

2- The pregnant women, at 24 to 32 years of age.

3- The pregnant women, at 32 to 41 years of age.

And, at five month of pregnancy every month recorded changes in variables until birth and one month after birth (6 moths). 
Hematological Measurements: An aliquot of blood was immediately taked and mixed with (EDTA) as an anticoagulant. These blood samples were analyzed for blood parameters using a full automated hematological analyzer (Celltac- $\alpha$ MEK-6400k, Nihon Kohdin Corporation, Tokyo, Japan) according to the manufacturer's protocol. The hematological parameters (WBC, $\mathrm{RBC}, \mathrm{MCH}, \mathrm{MCV}$, MCHC, HB, PLT, and PCV) were analyzed on the same day were the blood samples collected (Nazli, 2010).

\section{Lipid Profile Tests:}

Determination of Total Cholesterol (TC):The enzymatic colorimetric method was used for total serum cholesterol determination using Elitech Diagnostic kits (France) (Liu and Lawn, 1995).

Determination of Triglyceride (TG):The Enzymatic colorimetric test was used for serum Triglyceride determination using standard Elitech Diagnostic's kits (France) (Bar et al., 2002).

Determination of HDL:The cholesterol HDL was estimated using Kit (ELITech), and autoanalyzer (FLEXOR EL200, ELITech clinical systems), (Zhao et al., 2000).

Determination of LDL :LDL was determined by applying Friedwald et al. (1972) formula; LDL (mg/dl) = Total cholesterol $-\mathrm{HDL}-\mathrm{TG} / 5$.

Determination of VLDL :VLDL level was determined by derivation from the following formula (Lorentsen and Henriksen , 1998):

VLDL cholesterol $(\mathrm{mg} / \mathrm{dl})=$ Triglycerides $/ 5$.

Serum Iron:The Serum iron was estimated using the Kit (BIOLABO), The enzymatic colorimetric method was used Serum iron concentration. (Douglas et al., 1984). 


\section{Diagram 1: Tests measurements of the study design:}

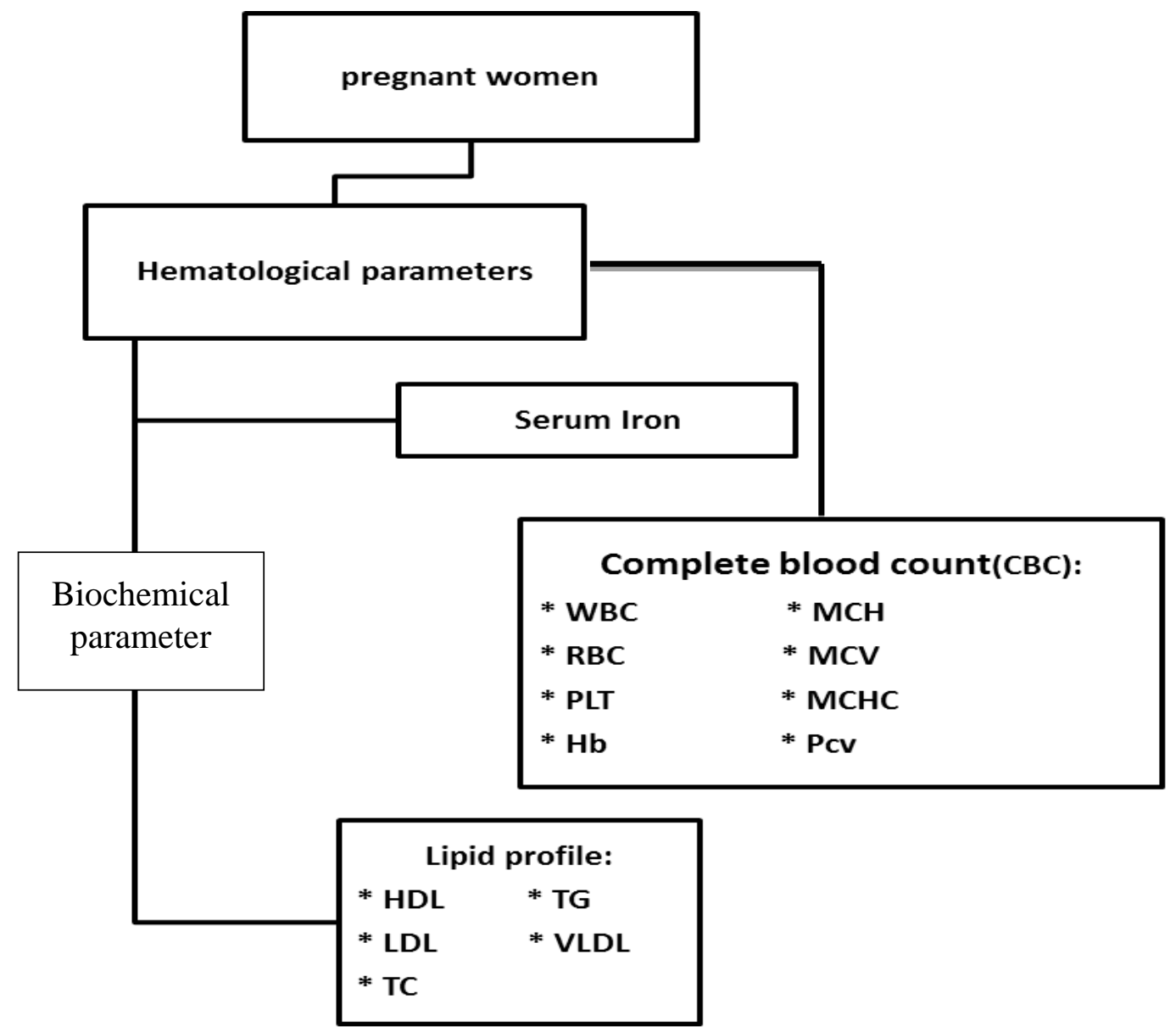

* WBC: White Blood Cells , RBC: Red Blood Cells, PLT: Platelets , HB: Hemoglobin, PCV: packed cell volume, MCV: Mean Corpuscular Volume, MCH: Mean Corpuscular Hemoglobin , MCHC: Mean Corpuscular Hemoglobin Concentration, TG: Triglyceride ,TC: Total Cholesterol, High-density lipoprotein (HDL), Low-density lipoprotein (LDL), Very low density lipoprotein (VLDL).

\section{RESULTS:}

The demographic and reproductive characteristics of the cases subjects investigated are summarized in (Table 1). Barqi, (2011) reported, the weight gain of underweight pregnant women in Sulaimani city-Iraq, reached to $18 \mathrm{Kg}$, and the overweight pregnant women reached to $6.8-11.4 \mathrm{Kg}$. 
Table 1: Information and distribution of cases (pregnant women).

\begin{tabular}{|c|c|c|c|}
\hline Group & Variables & Frequency & Percentage \\
\hline Age of & $16-24$ & 18 & $30 \%$ \\
pregnant & $24-32$ & 25 & $41.7 \%$ \\
Women (year) & $32-41$ & 17 & $28.3 \%$ \\
\hline & primigravidas & & \\
Puarity & 3 & 24 & $40 \%$ \\
& & 22 & $36.7 \%$ \\
& 3 & 14 & $23.3 \%$ \\
delivery & Normal & 49 & $81.7 \%$ \\
& Cesarean section & 11 & $18.3 \%$ \\
\hline Gestational & & & \\
weight & - & $4-14 \mathrm{~kg}$ & - \\
gain(GWG) & & & $26.7 \%$ \\
\hline Education of & Illiterate & 16 & $61.7 \%$ \\
pregnant & Read \&write & 37 & $11.6 \%$ \\
women & College & 7 & $6.6 \%$ \\
\hline Income (life & High & 4 & $21.7 \%$ \\
economy) & Medium & 43 & \\
\hline
\end{tabular}

Figure 1 shows, the weight of postpartum women, return to amount of plasma and fat stores gestation weight gain, and this fat stores decrease with breastfeeding (suckling) of infants. However, after birth, the second group swiftly return to their normal weight before pregnancy while the first group does not get their pre-pregnancy weight easily. The weight increase in the third group was less from the other two groups. 


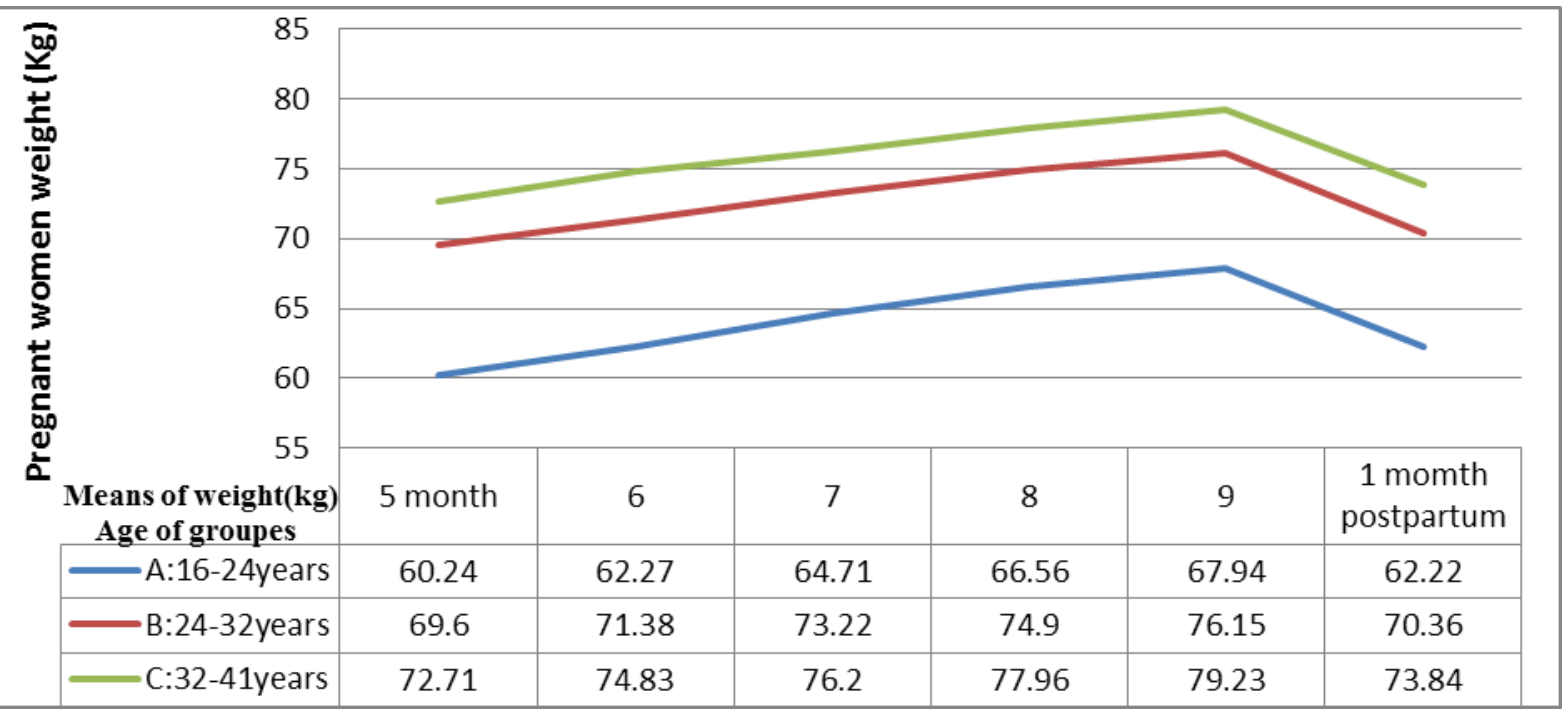

Figure 1: Curves changing of weight $(\mathrm{Kg})$ during six months for three age groups of pregnant women.

\section{Changes of hematological parameters in pregnant women:}

The aim of the present study was also to evaluate the hematological changes/variation that occur during normal pregnancy. From the presented results in Figure 2 and 3, showed that there were a difference in the PCV and $\mathrm{Hb}$ tests groups when compared between the different age groups (the total means Hb \& PCV of three groups A, B, C respectively were 11.96, 12.18, $11.96 \mathrm{mg} / \mathrm{dl}$ and 36.65, 37.18, $36.28 \%$ ) and the results were unstable during months of pregnancy. The greater $\mathrm{Hb}$ and PCV were recorded by group B, but in general there were in normal rang in this study. This findings were in agreement with those of James et al. (2008); WHO, (2004). The decrease in PCV and $\mathrm{Hb}$ may be due to increase in plasma volume during pregnancy which causes hemodilution, hormonal changes, and conditions that promote fluid retention and iron deficiency (Ichipi-Ifukor et al., 2013). 


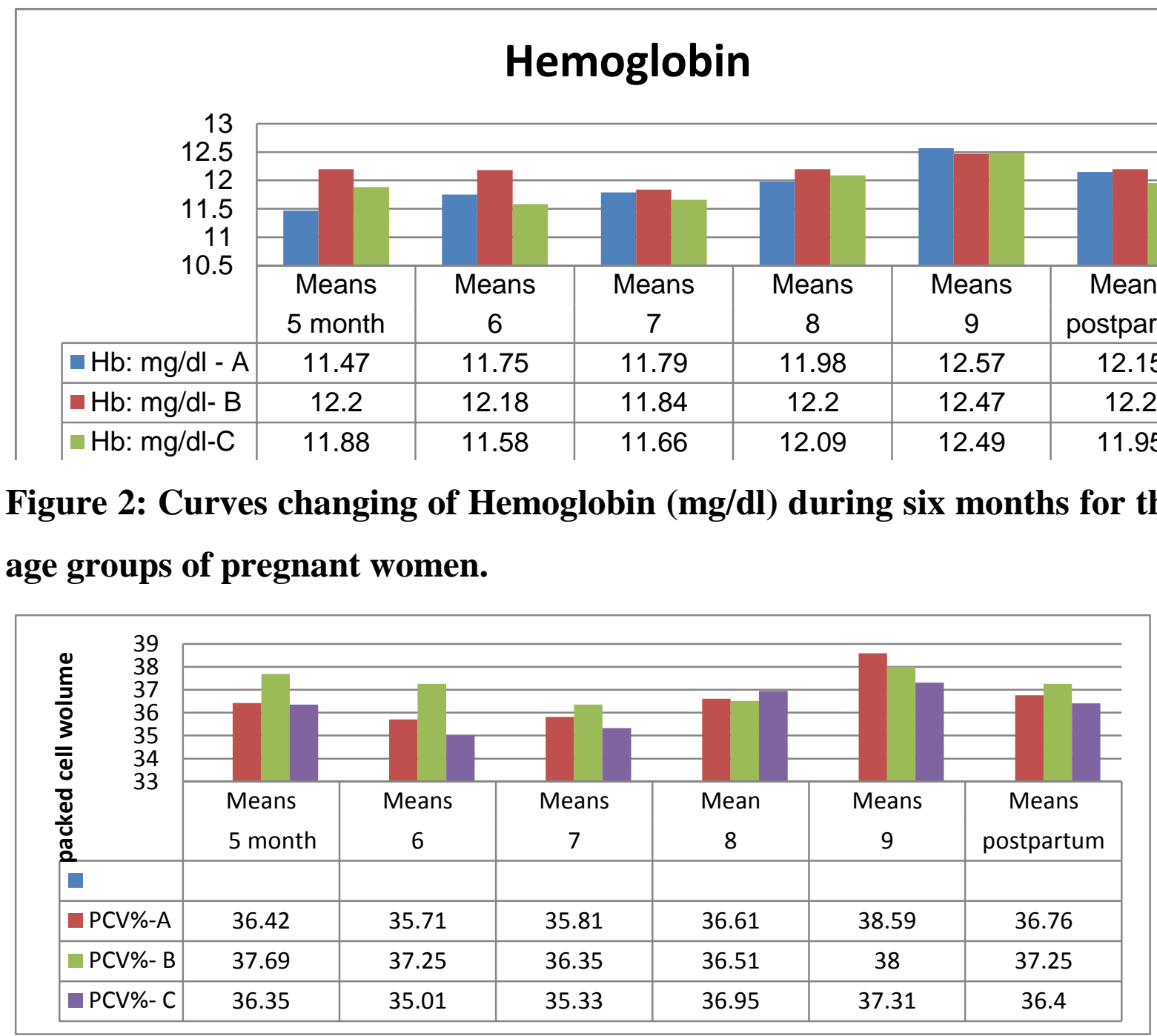

Figure3: Curves changing of packed cell volume (\%) during six months for three age groups of pregnant women.

The results of CBC count Convergent those; Osonuga et al., (2011); Wahed et al., (2008). Table 2, showed the result of CBC tests at second trimester, third trimester and post-partum of pregnant women. The results shows that the means of most $\mathrm{CBC}$ tests (RBC, PLT, Hb, PCV, MCH, MCV, MCHC) were slightly decreased in third trimester in comparison with the second trimester, yet the WBC value inversely slightly increased at the second trimester. A result of blood volume increasing the blood concentration diluted (WHO, 2005). 
Table 3: Data of CBC tests during last 5 months of pregnancy and postpartum.

\begin{tabular}{|c|c|c|c|c|c|c|c|c|}
\hline $\begin{array}{c}\text { Variabl } \\
\mathrm{e}\end{array}$ & $\begin{array}{c}\text { pregnanc } \\
y\end{array}$ & $\begin{array}{c}5 \text { mon } \\
\text { th }\end{array}$ & 6 montr & $\begin{array}{c}7 \text { mont } \\
h\end{array}$ & $\begin{array}{c}8 \text { mont } \\
h\end{array}$ & $\begin{array}{c}9 \text { mont } \\
h\end{array}$ & $\begin{array}{c}\text { postpar } \\
\text { tum }\end{array}$ & Total \\
\hline \multirow{4}{*}{$\begin{array}{c}\text { WBC } \\
\text { (white } \\
\text { Blood } \\
\text { Cell) } \\
\left(10^{3} / \mu \mathrm{L}\right)\end{array}$} & Mean & 8.49 & 9.33 & 9.26 & 8.81 & 8.85 & 8.55 & 8.88 \\
\hline & $\begin{array}{l}\text { Std. } \\
\text { Error }\end{array}$ & $\begin{array}{c} \pm \\
0.32\end{array}$ & $\begin{array}{c} \pm \\
0.29\end{array}$ & \pm 0.38 & \pm 0.22 & \pm 0.28 & \pm 0.27 & \pm 0.12 \\
\hline & $\underset{\mathrm{m}}{\operatorname{Minimu}}$ & 2.2 & 5.5 & 3.9 & 5.3 & 1.3 & 3.9 & 1.3 \\
\hline & $\begin{array}{l}\text { Maxim } \\
\text { um }\end{array}$ & 15.7 & 18.8 & 24.7 & 12.4 & 15.7 & 14.6 & 24.7 \\
\hline \multirow{4}{*}{$\begin{array}{c}\text { RBC } \\
\text { (Red } \\
\text { Blood } \\
\text { Cell) } \\
\left(10^{6} / \mu \mathrm{L}\right)\end{array}$} & Mean & 4.1 & 4.04 & 4.06 & 4.08 & 4.19 & 4.15 & 4.1 \\
\hline & $\begin{array}{l}\text { Std. } \\
\text { Error }\end{array}$ & $\begin{array}{c} \pm \\
0.05\end{array}$ & $\begin{array}{c} \pm \\
0.05\end{array}$ & \pm 0.04 & \pm 0.06 & \pm 0.06 & \pm 0.06 & \pm 0.02 \\
\hline & $\begin{array}{c}\text { Minimu } \\
\mathrm{m}\end{array}$ & 3.35 & 3.36 & 3.53 & 3.15 & 3.43 & 3.37 & 3.15 \\
\hline & $\begin{array}{l}\text { Maxim } \\
\text { um }\end{array}$ & 5.7 & 5.7 & 5.01 & 5.3 & 4.91 & 5.35 & 5.7 \\
\hline \multirow{4}{*}{$\begin{array}{r}\text { PLT } \\
\text { (Platlat } \\
\mathrm{e}) \\
\left(10^{3} / \mu \mathrm{L}\right)\end{array}$} & Mean & $\begin{array}{c}213 . \\
2\end{array}$ & $\begin{array}{c}220 . \\
3\end{array}$ & $\begin{array}{c}222.6 \\
6\end{array}$ & $\begin{array}{c}224.0 \\
9\end{array}$ & $\begin{array}{c}230.7 \\
4\end{array}$ & 233.63 & $\begin{array}{c}224.0 \\
5\end{array}$ \\
\hline & $\begin{array}{l}\text { Std. } \\
\text { Error }\end{array}$ & $\begin{array}{c} \pm \\
6.37\end{array}$ & $\begin{array}{c} \pm 6.2 \\
7\end{array}$ & \pm 6.81 & \pm 7.09 & \pm 6.85 & \pm 8.14 & \pm 2.84 \\
\hline & $\begin{array}{c}\text { Minimu } \\
\mathrm{m}\end{array}$ & 121 & 121 & 112 & 103 & 117 & 134 & 103 \\
\hline & $\begin{array}{c}\text { Maxim } \\
\text { um }\end{array}$ & 337 & 381 & 370 & 354 & 370 & 432 & 432 \\
\hline \multirow{4}{*}{$\begin{array}{r}\mathrm{Hb} \\
\text { (Hemog } \\
\text { lob-in) } \\
\text { (mg/dL) }\end{array}$} & Mean & 11.9 & $\begin{array}{c}11.8 \\
8\end{array}$ & 11.77 & 12.12 & 12.48 & 12.15 & 12.05 \\
\hline & $\begin{array}{l}\text { Std. } \\
\text { Error }\end{array}$ & $\begin{array}{c} \pm \\
0.13\end{array}$ & $\begin{array}{c} \pm \\
0.16 \\
\end{array}$ & \pm 0.15 & \pm 0.18 & \pm 0.18 & \pm 0.16 & \pm 0.07 \\
\hline & $\begin{array}{c}\text { Minimu } \\
\mathrm{m}\end{array}$ & 8.8 & 9.7 & 9.1 & 9.1 & 10 & 9.87 & 8.8 \\
\hline & $\begin{array}{c}\text { Maxim } \\
\text { um }\end{array}$ & 14.4 & 15.1 & 15.1 & 15.1 & 15.3 & 14.9 & 15.3 \\
\hline \multirow{2}{*}{$\begin{array}{c}\text { PCV } \\
\text { (Peaked } \\
\text { Cell } \\
\text { Volume }\end{array}$} & Mean & $\begin{array}{c}36.9 \\
6\end{array}$ & $\begin{array}{c}36.1 \\
6\end{array}$ & 35.93 & 36.73 & 37.92 & 36.95 & 36.77 \\
\hline & $\begin{array}{l}\text { Std. } \\
\text { Error }\end{array}$ & $\begin{array}{c} \pm \\
0.45\end{array}$ & $\begin{array}{c} \pm \\
0.51\end{array}$ & \pm 0.49 & \pm 0.53 & \pm 0.54 & \pm 0.45 & \pm 0.20 \\
\hline
\end{tabular}




\begin{tabular}{|c|c|c|c|c|c|c|c|c|}
\hline \multirow[t]{2}{*}{$\begin{array}{c}\text { ) } \\
(\%)\end{array}$} & $\begin{array}{c}\text { Minimu } \\
\mathrm{m}\end{array}$ & 28.4 & 28.3 & 28.3 & 28.5 & 30.6 & 30.3 & 28.3 \\
\hline & $\begin{array}{c}\text { Maxim } \\
\text { um }\end{array}$ & 45.5 & 44.7 & 44.7 & 45.5 & 49 & 44.6 & 49 \\
\hline \multirow{4}{*}{$\begin{array}{r}\mathrm{MCH} \\
\text { Mean } \\
\text { Corpusc } \\
\text { ular } \\
\text { Hemogl } \\
\text { obin } \\
\text { (pg) }\end{array}$} & Mean & $\begin{array}{c}29.2 \\
9\end{array}$ & $\begin{array}{c}29.6 \\
3\end{array}$ & 29.13 & 29.88 & 29.89 & 29.42 & 29.53 \\
\hline & $\begin{array}{l}\text { Std. } \\
\text { Error }\end{array}$ & $\begin{array}{c} \pm \\
0.41\end{array}$ & $\begin{array}{c} \pm \\
0.40\end{array}$ & \pm 0.40 & \pm 0.33 & \pm 0.32 & \pm 0.33 & \pm 0.15 \\
\hline & $\begin{array}{c}\text { Minimu } \\
\mathrm{m}\end{array}$ & 20.1 & 21.7 & 21.1 & 22.1 & 21.6 & 23 & 20.1 \\
\hline & $\begin{array}{l}\text { Maxim } \\
\text { um }\end{array}$ & 35 & 33.4 & 34 & 34.5 & 33.4 & 33.3 & 35 \\
\hline \multirow{4}{*}{$\begin{array}{c}\text { MCV } \\
\text { (Mean } \\
\text { Corpusc } \\
\text { ular } \\
\text { Volume } \\
\text { ) (fL) }\end{array}$} & Mean & $\begin{array}{c}91.0 \\
2\end{array}$ & $\begin{array}{c}90.0 \\
9\end{array}$ & 88.8 & 90.42 & 90.83 & 89.45 & 90.1 \\
\hline & $\begin{array}{l}\text { Std. } \\
\text { Error }\end{array}$ & $\begin{array}{c} \pm 1.2 \\
3\end{array}$ & $\begin{array}{c} \pm 1.1 \\
8\end{array}$ & \pm 1.21 & \pm 1.03 & \pm 0.95 & \pm 0.88 & \pm 0.44 \\
\hline & $\begin{array}{c}\text { Minimu } \\
\mathrm{m}\end{array}$ & 66.2 & 68.5 & 65.9 & 67.4 & 68 & 67.5 & 65.9 \\
\hline & $\begin{array}{c}\text { Maxim } \\
\text { um }\end{array}$ & $\begin{array}{c}109 . \\
2\end{array}$ & $\begin{array}{c}105 . \\
8 \\
\end{array}$ & 110.9 & 106.2 & 104.8 & 100.8 & 110.9 \\
\hline \multirow{4}{*}{$\begin{array}{r}\text { MCHC } \\
\text { Mean } \\
\text { Corpusc } \\
\text { ular } \\
\text { Hemogl } \\
\text { obin } \\
\text { Concen } \\
\text { tration } \\
\text { (g/dL) }\end{array}$} & Mean & $\begin{array}{c}32.1 \\
9 \\
\end{array}$ & $\begin{array}{c}32.8 \\
5 \\
\end{array}$ & 32.98 & 33.07 & 32.93 & 32.88 & 32.81 \\
\hline & $\begin{array}{l}\text { Std. } \\
\text { Error }\end{array}$ & $\begin{array}{c} \pm \\
0.27 \\
\end{array}$ & $\begin{array}{c} \pm \\
0.17 \\
\end{array}$ & \pm 0.21 & \pm 0.17 & \pm 0.19 & \pm 0.15 & \pm 0.08 \\
\hline & $\begin{array}{c}\text { Minimu } \\
\mathrm{m}\end{array}$ & 27.4 & 29.6 & 30.1 & 28.4 & 29.2 & 30.8 & 27.4 \\
\hline & $\begin{array}{l}\text { Maxim } \\
\text { um }\end{array}$ & 41.3 & 35.4 & 41.3 & 35.8 & 37.1 & 35 & 41.3 \\
\hline
\end{tabular}

Figure 4 shows, there is a significant difference in the three groups through the following up process of the pregnant in this study $(\mathrm{p}<0.05)$ and normally the serum iron variable during the six months. But the means low level iron in serum was $86.63 \mu \mathrm{g} / \mathrm{dl}$ group A and high level was $96.95 \mu \mathrm{g} / \mathrm{dl}$ in group C. so the greater level serum iron was in greater age (32-41years) and low level serum iron was in 
younger pregnant women (16-24years). In all groups, serum iron decreased in post-partum. As shown in Table 15, serum iron level in last 5 months of pregnancy almost increased but in postpartum decreased, and Table 16, show serum iron in the second trimester $(85.41 \mu \mathrm{g} / \mathrm{dl})$, third trimester $(93.57 \mu \mathrm{g} / \mathrm{dl})$ this change refer to storage iron in neonatal after birth and obstetric hemorrhage (WHO, 2001).

During pregnancy, in women with adequate iron stores at conception, the serum ferritin concentration initially rises, followed by a progressive fall by 32 weeks to about $50 \%$ pre-pregnancy levels. This is due to hemodilution and mobilization of iron. The levels increase again mildly in the third trimester (Asif et al, 2007).

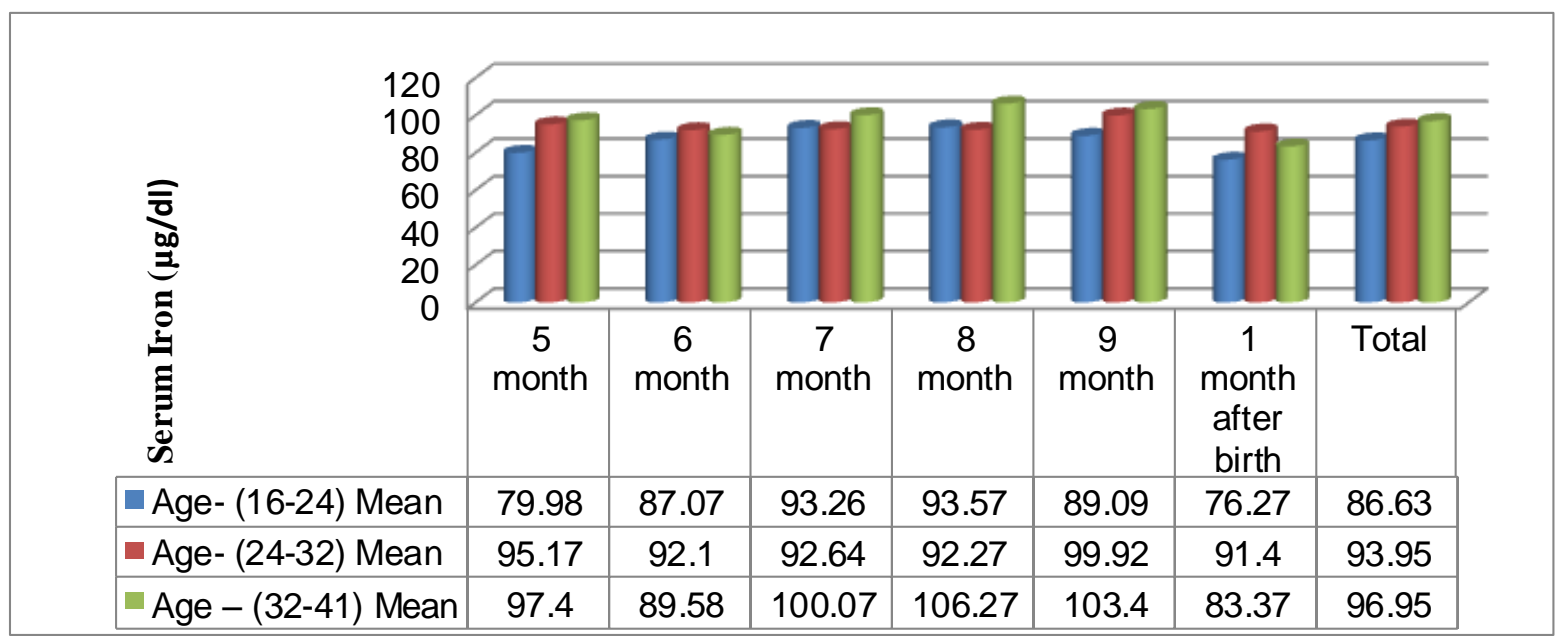

Figure 4: The means of serum iron during six months for three groups pregnant women.

Figure 5, 6 and 7 have shown data's means of Triglycerides (TG), cholesterol (TC) and HDL in three groups of age during 6 months. TG and TC were increased with the increased of the age category in the blood serum, generally during last 5 month of pregnancy were increased but in postpartum decreased. The increase was more in the first group (A) and the third while the second groups were more balanced through the changes. However, the level of HDL were conversely with TG and TC results which decrease with increased of age and gestation period. 
The changes in TC and TG had a direct relationship with women's age and months of pregnancy, i.e. the older the pregnant, especially in the last months, the reason can be the composition of fatty tissue under the skin of the fetus and also the use of fat in the composition of breast milk (Bayhan et al., 2005). But in general, as average, HDL decreased during pregnancy and even postpartum. The average of the second group was larger than the other two groups.

The means for three groups of TG $(159.11,174.24$ and $223.13 \mathrm{mg} / \mathrm{dl}$ respectively), TC (204.70, 214.64 and $223.17 \mathrm{mg} / \mathrm{dl})$ and $\mathrm{HDL}$ (53.98, 56.03 and $54.45 \mathrm{mg} / \mathrm{dl})$.

Table 4, shown changed lipid profile during second, third and post-partum. There was difference presence between three stages of pregnant women, but it was non-significant and the level of mean lipid profile unstable.

The increase of serum lipids through pregnancy in general and during pregnancy induced hypertension in particular is described in a number of studies. Worldwide diverse studies have reported (Sattar et al., 1997; Seely and Solomon, 2003; Turpin et al., 2008) elevated lipid levels in pregnancy induced hypertension patients. Some earlier studies reported that the striking changes in the lipid profile in normal pregnancy is serum hypertriglyceridemia, which may be as high as two to three folds in the third trimester over the levels in non-pregnant women .

Convergent results were reported by Bayhan et al., (2005); Nazli, (2010) in Pakistan. Their studies were aimed to estimate changes in lipid profile, serum levels of normal pregnancy. 


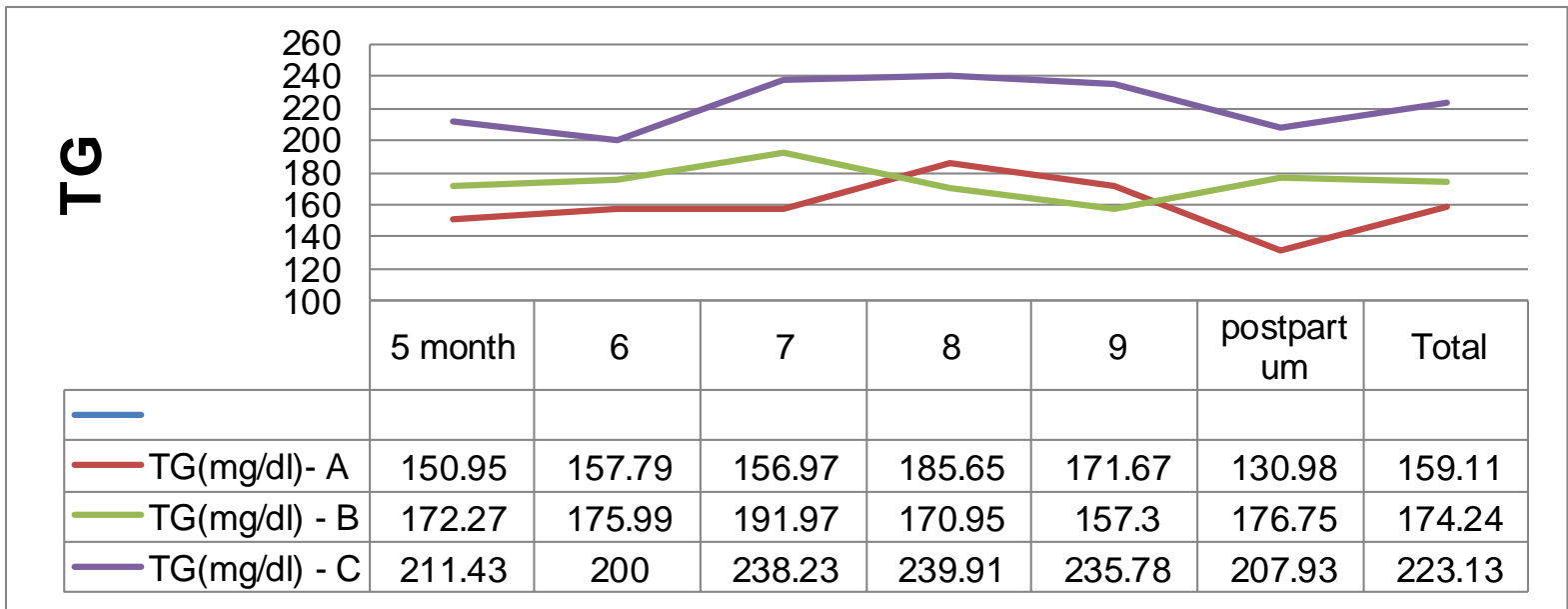

Figure 5: The means of TG during pregnancy and postpartum.

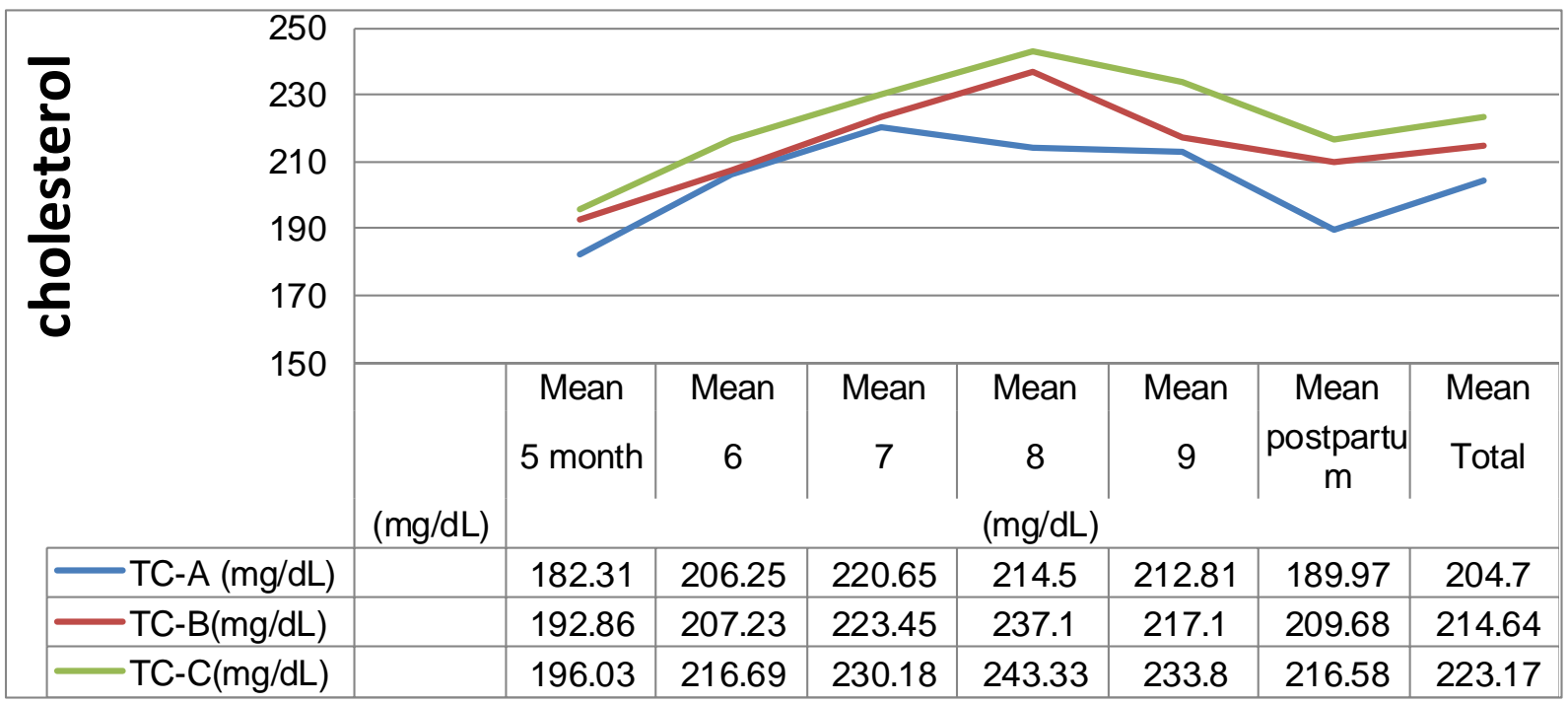

Figure 6: The means of TC during pregnancy and postpartum.

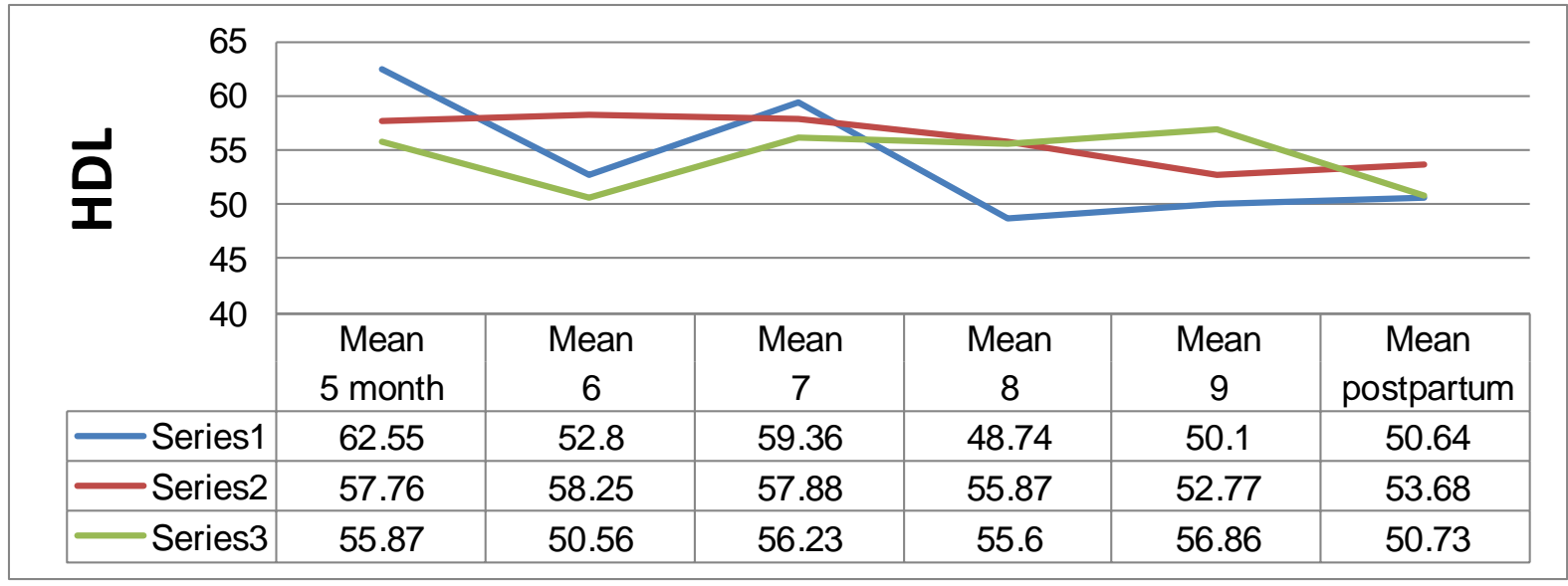

Figure 7: The means of HDL during pregnancy and postpartum. 
Table 4: Data of lipid profile, for pregnant women.

\begin{tabular}{|c|c|c|c|c|c|c|}
\hline variables & $\begin{array}{c}\text { During } \\
\text { pregnancy }\end{array}$ & Mean & $\begin{array}{c}\text { Std. } \\
\text { Error }\end{array}$ & $\begin{array}{c}\mathrm{t} \text {-test } \\
p<0.05\end{array}$ & Minimum & Maximum \\
\hline \multirow{3}{*}{$\begin{array}{l}\text { Triglycerides } \\
\text { (TG) } \\
\quad(\mathbf{m g} / \mathbf{d L})\end{array}$} & Second & 171.61 & 8.78 & N.S & 77 & 380 \\
\hline & Third & 173.98 & 7.29 & N.S & 57 & 440 \\
\hline & Postpartum & 184.12 & 7.49 & N.S & 79 & 327 \\
\hline \multirow{3}{*}{$\begin{array}{c}\text { Total } \\
\text { Cholesterol } \\
(\mathrm{mg} / \mathrm{dL})\end{array}$} & Second & 205.22 & 6.23 & N.S & 130 & 430 \\
\hline & Third & 194.23 & 5.71 & 0.05 & 65 & 332 \\
\hline & Postpartum & 217.38 & 4.71 & N.S & 140 & 305 \\
\hline \multirow{3}{*}{ HDL (mg/dL) } & Second & 51.58 & 1.79 & N.S & 28 & 87 \\
\hline & Third & 55.32 & 1.59 & N.S & 17 & 78 \\
\hline & Postpartum & 52.93 & 1.58 & N.S & 30 & 89 \\
\hline \multirow{3}{*}{ LDL(mg/dL) } & Second & 120.46 & 5.71 & N.S & 48 & 292 \\
\hline & Third & 104.15 & 4.71 & N.S & 29 & 220 \\
\hline & Postpartum & 127.43 & 4.05 & N.S & 65 & 195 \\
\hline \multirow{3}{*}{ VLDL(mg/dL) } & Second & 34.18 & 1.75 & N.S & 15.00 & 76.00 \\
\hline & Third & 76.03 & 3.06 & N.S & 40.00 & 187.00 \\
\hline & Postpartum & 131.32 & 3.59 & 0.05 & 65.00 & 189.00 \\
\hline
\end{tabular}

* S.E.M: Standard Error of Mean, N.S: $\mathrm{p}<0.05$ :not significant.

\section{References:}

American Diabetes Association (ADA), (2012) "Diagnosis and Classification of Diabetes Mellitus,” Diabetes Care, Vol. 35, Suppl. 1, 2012, pp. S64-S69.

Asif, N.; Hassan, K.; Mahmud, S.; Abbass Zaheer, H.; Naseem, L.; Zafar, T. and Shams, R. (2007) "Comparison of serum ferritin levels in three trimesters of pregnancy and their correlation with increasing gravidity." International Journal of Pathology 5, 26-30.

Bar J, Harell D, Bardin R, Pardo J, Chen R, Hod M, Sullivan M. (2002), "The elevated plasma lipoprotein(a) concentrations in pre-eclampsia do not precede the development of the disorder." Thrombosis Res 2002; 105: 19-23. 203. 
Barqi, A. (2011) "Nutritional status and some biochemical and healthy indexes in Sulaimania." .Centers for Disease Control and Prevention (CDC), (2014), “1600 Clifton Road Atlanta”, GA 30329-4027, USA

Centre for Disease Control and Prevention (CDC), (2005) "Use of supplements containing folic acid among women child beareu age. United states," 2005.

Crane, JM.; White, J.; Murphy, P.; Burrage, L.; Hutchens, D. (2009), “The effect of gestational weight gain by body mass index on maternal and neonatal outcomes.” J Obstet Gynaecol Can. 2009;31(1):28-35.

Douglas, J.; Gary, R.; Reid, E and Stephan L. (1984) “FERENE: A new spectrophotometric reagent for iron ." CAN J.Chem.62p . 721-724.

Fahraeus, L.; Larsson - Cohn, U. and Wallentin, L. (1995) "Plasma lipoproteins including high density lipoprotein subfractions during normal pregnancy.”Obstet. Gynecol 66:468 - 472 .

Frederick, IO.; Williams, MA.; Sales, AE.; Martin, DP. and Killien, M. (2008) "Prepregnancy body mass index, gestational weight gain, and other maternal characteristics in relation to infant birth weight". Matern Child Health J. 2008;12(5):557-67.

Friedwald, W.; Levy, P. and Fredrickson, D. (1972) "Estimation of concentration of low density lipoprotein cholesterol in plasma, without use of the preparative centrifuge." Clin Chem 1972; 18:499-502.

Garn, S.; Keating, M. and Falkner, F. (1981)a "Hematological status and pregnancy outcomes," The American Journal of Clinical Nutrition, vol. 34, no. 1, pp. $115-117,1981$.

http://krg.org/articles/detail.asp?lngnr=12\&smap=03010300\&rnr=140\&anr=23911.

Ichipi-Ifukor, P.; Juliet, J.; Rita, N. and Oberhiri L. (2013) "Changes in Haematological Indices in Normal Pregnancy" Hindawi Publishing Corporation Physiology Journal Volume 2013, Article ID 283814, 4 pages http://dx.doi.org/10.1155/2013/283814. 
Jimenez, D. ; Pocovi, M. and Ramon, C. (1988) "Longitudinal Study of Plasma Lipids and Lipoprotein Cholesterol in Normal Pregnancy and Puerperium” Invest.

James, T. ; Reid, H. and Mullings A. (2008) "Are published standards for haematological indices in pregnancy applicable across populations: an evaluation in healthy pregnant Jamaican women," BMC Pregnancy and Childbirth, vol. 8, article 8, 2008.

Lorentsen, B. and Henriksen, T. (1998), Plasma lipids and vascular dysfunction in pre-eclampsia. Semin Reprod. Endocrinol. 1998; 16: 33-39.

Liu, A. and Lawn, R. (1995), "Vascular interactions of lipoprotein (a)." Curr Opin Lipidol 1995; 5:269-73.

Ministério, d. (2005) Secretaria de Atenção à Saúde. Departamento de Ações Programáticas Estratégicas. Área Técnica de Saúde da Mulher. Pré-natal e puerpério: atenção qualificada e humanizada - manual técnico. Brasília: Ministério da Saúde; 2005.

Nazli, B. (2010) "Lipid metabolism study in women of pregnancy induced hypertension cases”, Ph.D THESIS, University of Peshawar ;NWFP- Pakistan

Osonuga, I. ; Osonuga, O.; Onadeko, A. ; Osonuga, A. and Osonuga A., (2011) "Hematological profile of pregnant women in southwest of Nigeria," Asian Pacific Journal of Tropical Disease , vol. 1, no. 3, pp. 232-234, 2011.

Potter, J. and Neste, P. (1979) "The hyperlipidemia of pregnancy in normal and complicated pregnancies.” Am. J. Obstet. Gynecol. 1979, 133; 165- 179.

Sattar, N.; Bendomir, A.; Berry, C.; Shepherd, J.; Greer, IA. an Packard, CJ. (1997) “ Lipoprotein subfraction concentrations in Pre-eclampsia: pathogenic parallels to atherosclerosis." Obstet Gynecol 1997; 89:403-8.

Seely, EW. and Solomon, CG. (2003) "Insulin resistance and its potential role in pregnancy induced hypertension.” J. Clin. Endocrinol. Metab.

Shaw, J.; Dey, S.; Critchley, H. and Horne, A. (2010) "Current knowledge of the aetiology of human tubal ectopic pregnancy," Human Reproduction Update, vol. 16, no. 4, Article ID dmp057, pp. 432-444, 2010. 
Stock, M. and Metcalfe, J. (1994) "Maternal physiology during gestation. In: Knobil, E. and Neil, J. D. (eds): The physiology of reproduction. Raven press, New York. 1994, Pp. 947 - 983.

Turpin, C.; Ahenkorah, L.; Owiredu, W.; Laing, E. and Amidu, N. (2008) "The prevalence of the metabolic syndrome among Ghanaian pregnancy induced hypertensive patients using the World health Organisation and the national Cholesterol Education Program III criteria.” J. Med. Sci. 2008; 8: 443-451.

Victoria, P.; Otilia, D.; Palamaru, I.; Adam, C.; Nicoleta, F. and Doina, D. ( 2001)

"MATERNAL HAEMATOLOGICAL AND BIOCHEMICAL PARAMETERS AND PREGNANCY OUTCOME". The journal of preventive medicine. , 2001; 9(3): 27-33.

Wahed, F.; Latif, M. and Mahmud, M. (2008) "Fact of low hemoglobin and packed cell volume in pregnant women are at a stand still," MymensinghMedical Journal, vol. 17, no. 1, pp. 4-7.

Wald, N. and Guckle, H. (1988) "Impact of Lipid Profile on Pregnancy Outcome in Urban Population". Br. Med. J. , 297: 883 - 887.

WHO (2002) " Essential Antenatal, Perinatal and Postpartum Care". Regional Office for Europe, WHO,2002.

WHO (2004) "Prevention and treatment of malaria during pregnancy," 2004, http://pdf.usaid.gov/pdf docs/Pnada621.pdf.

WHO (2001) "Iron deficiency anemia: a assessment, prevention and control". United Nations Children's Fund, United Nation University. A guide for programme managers. Geneva: WHO, 2001.

WHO (2005); World Health Organization . Food \& Nutrition .Clinical \& Universal Book. Academia International 2th ed .ISBN:9953-3-0082-8.

Zhao Y, Tang H, Liu S. (2000), "Serum lipoprotein (a) in woman with pregnancy induced hypertension.” Zhonghua Fu Chan Ke Za Zhi. 2000;35:145-7. 